\title{
Cannibalism in the Smith Frog, Hypsiboas faber (Wied-Neuwied, 1821), in Southern Brazil
}

Fábio Maffei ${ }^{1}$, Bruno Tayar Marinho do Nascimento ${ }^{1}$, and Paulo Sérgio Bernarde ${ }^{2}$

${ }^{1}$ Departamento de Ciências Biológicas, Faculdade de Ciências, Universidade Estadual Paulista - UNESP, CEP 17033-360, Bauru, SP, Brazil (maffei.fabio@gmail.com)

${ }^{2}$ Laboratório de Herpetologia, Centro Multidisciplinar, Universidade Federal do Acre - UFAC,

Campus Floresta, CEP 69980-000, Cruzeiro do Sul, AC, Brazil

$\mathrm{A}_{\mathrm{p}}^{\mathrm{n}}$ mphibians have a generalized diet, but adults are always predators. Most are insectivorous, but several species feed on small vertebrates. Some of the latter feed sporadically on frogs (batracophagy; Toledo et al. 2006, Figueiredo-deAndrade et al. 2012). Cannibalism in anurans is well known in tadpoles (e.g., McDiarmid and Altig 1999). Among adult anurans, however, it is rare; when it does happen, it usually involves preying on young (Wells 2007, Wiseman and Bettaso 2007, Hobel 2011, Struijk et al. 2014) and tends to occur most frequently in non-arboreal species (Toledo et al. 2006, Wells 2007). This behavior is considered an opportunistic form of predation (Duellman and Trueb 1994).

The Smith Frog (Hypsiboas faber) is large (SVL to 90 $\mathrm{mm}$ ) and very common along forest edges and in open areas of Atlantic Forest from northern Argentina and southeastern Paraguay to northeastern Brazil (Haddad et al. 2013, Frost 2014). Vocalization resembles the hammering of a blacksmith. Males have a prepolex with a spine similar to a thumb, which is used in combat with other males (Maffei and Ubaid 2014). Reproduction involves mud nests built by the male at the edge of bodies of water (Martins 1993). The species' natural history is well documented, and includes numerous records of prey and predators (e.g., Martins et al. 1993, Pombal Jr. 2007, Toledo et al. 2007, Forti and Bertoluci 2012).

On 30 December 2013 at $2355 \mathrm{~h}$, we observed a male Hypsiboas faber preying on a newly metamorphosed individual of the same species (Fig. 1). The male was perched on grass (Panicum maximum) about $1 \mathrm{~m}$ above the ground at Rio Claro Farm in Lençóis Paulista Municipality, São Paulo State, in southern Brazil (22 $46^{\circ} 35.47^{\prime \prime S} 48^{\circ} 53^{\prime} 52.54^{\prime \prime W}$, a.s.l. 650 $\mathrm{m})$. Habitat was riparian forest at the edge of a semi-permanent body of water in a transition area between the Cerrado and Atlantic Forest. The individuals were collected and deposited in the Amphibian Collection of the Department of Zoology at São Paulo State University, São José do Rio Preto Municipality, São Paulo State, Brazil (voucher numbers: 14517 and 14519).

Cannibalism of adults has been documented in some treefrogs (Hylidae), including Hyla cinerea (Höbel 2011) and Acris crepitans (McCallum et al. 2001). This behavior may be associated with situations of high population density or low food resources, and could provide possible advantages such as obtaining energy while decreasing intraspecific competition. In fact, greater availability of food per individual has been shown to increase survival rates (e.g., Crump 1983, Doubledee et al. 2003). However, cannibalism by adults in large cohorts can reduce or completely eliminate subsequent recruitment for years (Whiteman and Wissinger 2005). Female Smith Frogs are known to deposit clutches of 1,0002,700 eggs (Martins and Haddad 1988). This reproductive mode (mode 4, sensu Haddad and Prado 2005) creates situations of high population densities, because larvae quickly metamorphose to avoid the risk of pools drying up (Martins 1993).

Recorded instances of batracophagy by Smith Frogs involve prey species that include Aplastodiscus perviridis and Scinax granulatus (Solé et al. 2004), Haddadus binotatus (Leite et al. 2008), Scinax aff. perereca (Moura and Feio 2010), and Dendropsophus meridianus (Figueiredo-de-Andrade et al. 2012). Of these, only $H$. binotatus is terrestrial. Predation by $H$. faber is more common on other hylids due to the numerous potential predator-prey encounters facilitated by a common arboreal lifestyle (Moura and Feio 2010, Loebmann 2013). However, cannibalism by Smith Frogs was previously documented only on tadpoles (Bernarde and Machado 1999). Metamorphosing froglets of $H$. faber are known prey of adults of other species of frogs (Leptodactylus cf. latrans, Haddad and 

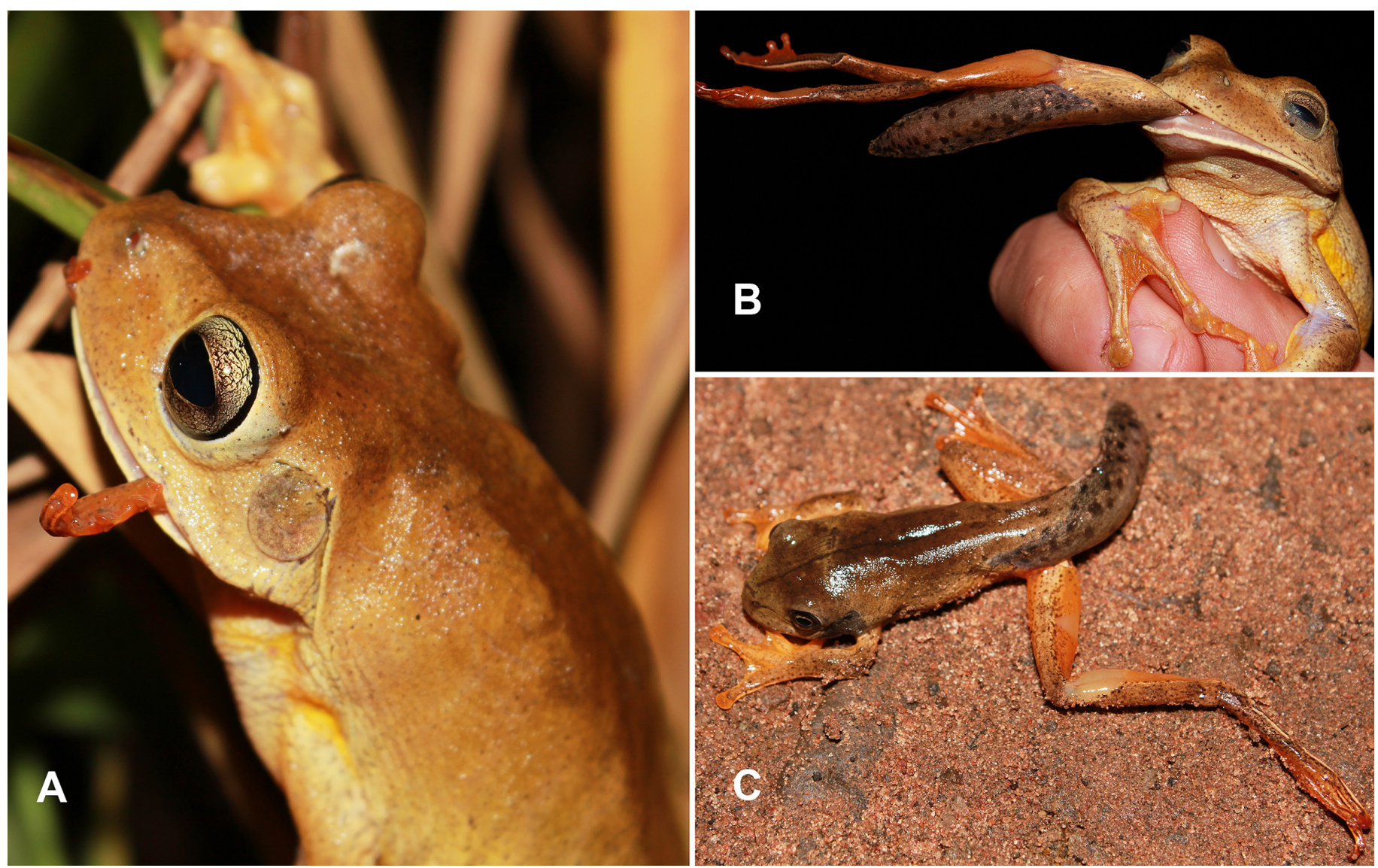

Fig. 1. Male Smith Frog (Hypsiboas faber) preying on a newly metamorphosed conspecific. (A) When first observed; (B) removal of the metamorph from the mouth of the adult; (C) the newly metamorphosed prey. Photograph by the senior author.

Sazima 1992, Pombal Jr. 1997), but this is the first record of cannibalism by $H$. faber preying on conspecific metamorphs.

\section{Acknowledgments}

Tunin Bernarde helped during fieldwork, Duratex S.A. provided access to the Rio Claro Farm and logistical support, Denise C. Rossa-Feres assisted with the deposition of specimens. The first author thanks CAPES for fellowship.

\section{Literature Cited}

Bernarde, P.S. and R.A. Machado. 1999. Hyla faber (Smith Frog). Larval cannibalism. Herpetological Review 30:162.

Crump, M.L. 1983. Opportunistic cannibalism by amphibian larvae in temporary aquatic environments. The American Naturalist 121:281-289.

Doubledee, R.A., E.B. Muller, and R.M. Nisbet. 2003. Bullfrogs, disturbance regimes, and the persistence of California Red-legged Frogs. Journal of Wildlife Management 67:424-438.

Duellman, W.E. and L. Trueb. 1994. Biology of Amphibians. Johns Hopkins University Press, Baltimore, Maryland.

Figueiredo-de-Andrade, C.A., J. Caram, and S.P. Carvalho-e-Silva. 2012. Frog eats frog: Report of three cases from the Atlantic rain forest, southeastern Brazil. Salamandra 48:230-232.

Forti, L.R. and J. Bertoluci. 2012. Distress call of Hypsiboas faber (Anura: Hylidae) during a Liophis miliaris (Serpentes: Colubridae) attack. Herpetology Notes 5:187-188.
Frost, D.R. 2014. Amphibian Species of the World: An Online Reference. Version 5.6. American Museum of Natural History, New York (http://research.amnh. org/herpetology/amphibia/index.php).

Haddad, C.F.B. and C.P.A. Prado. 2005. Reproductive modes in frogs and their unexpected diversity in the Atlantic Forest of Brazil. BioScience 55:207-217.

Haddad, C.F.B. and I. Sazima. 1992. Anfíbios anuros da Serra do Japi, pp. 188211. In: L.P.C. Morellato (org.), História Natural da Serra do Japi: Ecologia e Preservação de uma Área Florestal no Sudeste do Brasil. Editora da UNICAMP/ FAPESP, Campinas, Brazil.

Haddad, C.F.B., L.F. Toledo, C.P.A. Prado, D. Loebmann, J.L. Gasparini, and, I. Sazima. 2013. Guia dos Anfibios da Mata Atlantica: Diversidade e Biologia. Anolis Books, São Paulo, Brasil (in Portuguese).

Hobel, G. 2011. Hyla cinerea (Green Treefrog). Cannibalism and defensive posture. Herpetological Review 42:85-86.

Leite, F.S.F., T.L, Pezzuti, and, L.O. Drummond. 2008. Hypsiboas faber (Smith Frog). Diet. Herpetological Review 39:206-207

Loebmann, D. 2013. A record of Trachycephalus typhonius (Linnaeus, 1758) preying upon Dendropsophus soaresi (Caramaschi \& Jim, 1983) (Anura, Hylidae). Herpetology Notes 6:275-276.

Maffei, F. and F.K. Ubaid. 2014. Amphibians of Rio Claro Farm, Lençóis Paulista, São Paulo, Brazil. Editora Canal 6, Bauru, Brazil.

Martins, M. 1993. Observations on nest dynamics and embryonic and larval development in the nest building Gladiator Frog, Hyla faber. Amphibia-Reptilia $14: 411-421$

Martins, M. and C.F.B, Haddad. 1988. Vocalizations and reproductive behaviour in the Smith Frog, Hyla faber Wied (Amphibia: Hylidae). Amphibia-Reptilia 9:49-60.

Martins, M., I. Sazima, and S.G. Egler. 1993. Predators of the nestbuilding Gladiator Frog, Hyla faber, in southeastern Brazil. Amphibia-Reptilia 14:307-309. 
McCallum, M.L, B.A. Wheeler, S.E. Trauth, and N.E. Karraker. 2001. Acris crepitans (Northern Cricket Frog). Attempted cannibalism. Herpetological Review 32:99-100.

McDiarmid, R.W. and R. Altig. 1999. Tadpoles: The Biology of Anuran Larvae. The University of Chicago Press, Chicago, Illinois.

Moura, M.R. and R.N. Feio. 2010. Hypsiboas faber (Wied-Neuwied) predation on Scinax aff. perereca (Anura: Hylidae) in southeastern Brazil. Herpetology Notes 3:353-354.

Pombal, J.P., Jr 2007. Predation notes in an anuran amphibian assemblage from southeastern Brazil. Revista Brasileira de Zoologia 24:841-843.

Solé, M., B. Pelz, and A. Kwet. 2004. Hypsiboas faber (Smith Frog). Diet. Herpetological Review 35:159.
Struijk, R.P.J.H., W. Bosman, and, J. Janse. 2014. Cannibalism in Bombina variegata Linnaeus, 1758 in Wahlwiller, Limburg Province, The Netherlands. Herpetology Notes 7:307-308.

Toledo, L.F., R.S. Ribeiro, and C.F.B. Haddad, 2007. Anurans as prey: An exploratory analysis and size relationships between predators and their prey. Journal of Zoology 271:170-177.

Wells, K.D. 2007. The Ecology and Behavior of Amphibians. The University of Chicago Press, Chicago, Illinois.

Whiteman, H.H. and S.A. Wissinger. 2005. Amphibian population cycles and long-term data sets, pp.177-184. In: M.J. Lannoo (ed.), Conservation and Status of North American Amphibians. University of California Press, Berkeley.

Wiseman, K.D. and J.B. Bettaso. 2007. Rana boylii. Cannibalism and predation. Herpetological Review 38:193. 